Journal of Islamic Studies and Humanities

Vol. 3, No. 1 (2018) 21-44

doi: http://dx.doi.org/ 10.21580/jish.11.2852

\title{
STRATEGI KEPALA LEMBAGA PENGEMBANGAN STUDI ISLAM (LPSI) UNIVERSITAS AHMAD DAHLAN YOGYAKARTA DALAM MENGINTERNALISASIKAN NILAI-NILAI RELIGIUS MAHASISWA
}

\author{
Rini Setyaningish \\ Universitas Islam Negeri Sultan Syarif Kasim Riau \\ rinisetyaningsih28@gmail.com
}

\begin{abstract}
This study aims to determine the strategy of the Head of the Institute for Development of Islamic Studies (LPSI) of Ahmad Dablan University Yogyakarta in internalizing religious values to students. The research method uses deskptive qualitative. The Chief Strategy of LPSI to internalize the religious values of students through the 3 stages, first, externalizing values where the LPSI collaborated with the Campus Introduction Program (PPK) committee in providing important information related to the campus Islamization program. second, certification Quranic activity supervisors and student organizations in providing Islamic knowledge. third, value internalization. in the academic realm and in the non-academic realm
\end{abstract}

Keywords: strategy; internalization; religious;

\begin{abstract}
Abstrak
Penelitian ini bertujuan untuk mengetahui strategi Kepala Lembaga Pengembangan Studi Islam (LPSI) Universitas Ahmad Dahlan Yogyakarta dalam menginternalisasikan nilai-nilai religius kepada mahasiswa. Metode penelitian mengunakan kualitatif deskptif. Strategi Kepala LPSI untuk menginternalisasikan nilai-nilai religius mahasiswa melalui 3 tahapan pertama, eksternalisasi nilai dimana pihak LPSI bekerjasama dengan panitia Program Pengenalan Kampus (PPK) dalam memberikan informasi penting terkait program Islamisasi kampus., kedua, objektivitas, pihak LPSI bekerjasama dengan seluruh dosen AIK dan sertifikasi, pembimbing kegiatan tahsinul-Qur'an dan organisasi mahasiswa dalam memberikan ilmu pengetahuan agama Islam. ketiga, internalisasi nilai dalam ranah akademik dan dalam ranah non-akademik.
\end{abstract}

Kata kunci: strategi; internalisasi; religius;

ISSN 2527-8401 (p) 2527-838X (e)

(C) 2018 JISH Pascasarjana UIN Walisongo Semarang

http://journal.walisongo.ac.id/index.php/jish 


\section{Pendahuluan}

Menurut Peraturan Pemerintah Nomor 19 Tahun 2005 pasal 5 tentang Standar Nasional Pendidikan dijelaskan bahwa pendidikan agama mendorong peserta didik untuk taat menjalankan ajaran agamanya dalam kehidupan sehari-hari. Selain itu juga menjadikan agama sebagai landasan etika dan moral dalam kehidupan pribadi, keluarga, masyarakat, bangsa, dan negara. Pendidikan agama dapat membangun sikap mental peserta didik yang baik. Peserta didik akan memiliki sikap dan perilaku jujur, amanah, bertanggung jawab, percaya diri, disiplin, bekerja keras, dan mandiri.

Pendidikan adalah keseluruhan usaha untuk mentransformasikan ilmu, pengetahuan, ide, gagasan, norma, hukum, dan nilai-nilai kepada orang lain dengan cara tertentu, baik struktural, formal, dan non-formal dalam suatu sistem pendidikan nasional. Produk pendidikan memiliki budaya yang didefinisikan masyarakat yang berperadaban, memiliki kebebasan yang merefleksikan kreatifitas dalam dinamikanya secara komprehensif menuju kehidupan yang sejahtera diatur oleh norma hukum yang kuat, sebagaimana dicita-citakan masyarakat dan bangsa.

Secara terperinci tujuan pendidikan Nasional dijelaskan dalam pasal 3 UUSPN Nomor 20 Tahun 2003: Pendidikan Nasional berfungsi mengembangkan kemampuan dan membentuk watak serta peradaban bangsa yang bermartabat dalam rangka mencerdaskan kehidupan bangsa, bertujuan untuk berkembangnya potensi peserta didik agar menjadi manusia yang beriman dan bertakwa kepada Tuhan Yang Maha Esa, berakhlak mulia, sehat, berilmu, cakap, kreatif, mandiri dan menjadi warga negara yang demokratis serta bertanggungjawab. ${ }^{1}$

${ }^{1}$ Chusnul dan Muhammad Fathurrohman Khotimah, Komplemen Manajemen Pendidikan Islam: Konsep Integratif Pelengkap Manajemen Pendidikan Islam (Yogyakarta: Teras, 2014), 233. 
Usaha penanaman nilai-nilai religius di Perguruan Tinggi dihadapkan pada berbagai tantangan baik secara internal maupun eksternal. Secara internal, pendidikan di Perguruan Tinggi dihadapkan pada masalah internal mahasiswa yang secara psikologis sudah mencapai usia dewasa. Begitu pula pada aspek pembelajaran lainnya, seperti kurikulum, sistem evaluasi dan kompetensi dosen. Secara eksternal, pembelajaran di Perguruan Tinggi dihadapkan pada masalah perkembangan zaman yang sangat susah dikendalikan. Contoh dalam hal ini adalah: etika pergaulan, perkembangan teknologi informasi dan masalah sosial lainnya. Menghilangkan semua masalah tersebut sangat jelas suatu hal yang tidak instan, namun dapat dilakukan apabila seluruh civitas akademika secara bersama-sama berusaha menghapuskan dampak negatif yang ditimbulkan dunia luar dengan merumuskan visi dan misi yang religius, pelaksanaan pembelajaran yang integratif dan penciptaan suasana yang religius.

Suasana kehidupan modern dengan kebudayaan yang sangat kuat serta terpenuhinya berbagai mobilitas kehidupan secara teknologis-mekanis, pada satu sisi telah melahirkan krisis etika dan moral. Munculnya fenomena white collar crime (kejahatan kerah putih atau kejahatan yang dilakukan oleh kaum berdasi) yang dilakukan oleh para elit, merupakan indikasi kongkrit bangsa Indonesia sedang mengalami krisis multidimensional. Melihat fenomena tersebut maka dapat disimpulkan bahwa kesalahan kecil bisa berakibat fatal karena masing-masing orang mengedepankan kepentingan dan egonya. Krisis moral tersebut tidak hanya melanda masyarakat lapisan bawah, tetapi juga meracuni atmosfir birokrasi negara mulai dari tingkat paling atas sampai paling bawah.

Perguruan Tinggi Islam diharapkan mampu mencetak figurfigur ulama' yang intelek profesional atau profesional yang ulama'. Oleh karena itu, Perguruan Tinggi Islam perlu untuk mengadakan perekonfigurasian tujuan institusionalnya dengan memperhatikan berbagai tuntutan masyarakat dan zaman yang terus berubah. Jika 
tidak, maka Pendidikan Tinggi Islam tidak pernah bartahan hidup dalam budaya dan umatnya sendiri seiring dengan pergeseran nilai yang semakin deras. ${ }^{2}$ Maka penanaman nilai-nilai religius di Perguruan Tinggi Islam sangat penting untuk dilakukan, agar terdapat keseimbangan antara penguasaan ilmu pengetahuan dan teknologi dengan penanaman keimanan dan ketakwaan. Sehingga dapat menghasilkan lulusan yang berkualitas tinggi, yakni selain memiliki pengetahuan dan keahlian juga memiliki bekal ilmu pengetahuan agama, moral, akhlak yang mulia, serta amal shalih.

\section{Strategi Kepala Lembaga}

Strategi adalah suatu seni menggunakan kecakapan dan narasumber daya suatu organisasi untuk mencapai sasarannya melalui hubungan yang efektif dengan lingkungan dalam kondisi yang paling menguntungkan. Konsep tersebut mengemukakan bahwa strategi lebih menekankan pengertiannya pada suatu situasi dimana pimpinan mampu mendayagunakan segenap sumber daya organisasi dengan tepat dan benar. Dalam hal ini, maka seorang pimpinan harus dituntut memiliki kepandaian dalam menguasai situasi dan kondisi yang dimiliki oleh organisasi, sehingga mampu menerapkan suatu pengembangan program dan menggerakkan sumber daya organisasi yang dimilikinya. ${ }^{3}$

Winardi mengemukakan bahwa strategi sebuah organisasi atau subnya merupakan konseptualisasi yang dinyatakan dan akan diimplikasikan oleh pimpinan organisasi yang bersangkutan, meliputi: sasaran-sasaran jangka panjang atau tujuan-tujuan organisasi tersebut, kendala-kendala luas dan kebijakan-kebijakan yang atau ditetapkan sendiri oleh sang pemimpin, atau yang diterimanya dari pihak atasannya yang membatasi skope aktivitas-

${ }^{2}$ Asmaun Sahlan, Religiusitas Perguruan Tinggi: Potret Pengembangan Tradisi Keagamaan Di Perguruan Tinggi Islam (Malang: UIN-Maliki Press, 2011), 3.

${ }^{3}$ Salusu Salusu, Strategi Pengambilan Keputusan (Jakarta: Pressindo, 2014), 101. 
aktivitas organisasi yang bersangkutan dan kelompok rencanarencana dan tujuan-tujuan jangka pendek yang telah diterapkan dengan ekspekasi akan diberikannya sumbangsih mereka dalam hal mencapai sasaran-sasaran organisasi tersebut. Lebih lanjut Winardi mengemukakan bahwa strategi merupakan pola sasaran, tujuan atau maksud dan kebijakan utama serta rencana untuk mencapai tujuan tersebut. Konsep tersebut lebih menitikberatkan pada upaya pimpinan dalam menetapkan sasaran yang harus dicapai organisasi melalui suatu perencanaan yang akurat, matang dan sistematis. Perencanan dalam hal ini merupakan suatu pola kebijakan tertentu dalam mengelola organisasi menuju tujuan yang telah ditetapkan. ${ }^{4}$ Sejalan dengan pengertian tersebut Glueck dalam bukunya Saladin, bahwa strategi adalah sebuah rencana yang disatukan luas dan terintegrasi, yang menghubungkan seunggulan strategi perusahaan dengan tantangan lingkungan dan yang dirancang untuk memastikan bahwa tujuan utama perusahaan dapat dicapai melalui pelaksanaan yang tepat oleh organisasi. ${ }^{5}$

Berdasarkan konsep tersebut, maka strategi merupakan suatu kesatuan rencana yang menyeluruh, komprehensif dan terpadu yang diarahkan untuk mencapai tujuan. Dengan demikian dapat disimpulkan bahwa bahwa strategi kepala lembaga merupakan rangkaian dari rencana sebagai sasaran, kebijakan atau tujuan yang ditetapkan oleh seorang kepala lembaga dalam pembelajaran sesuai dengan kondisi yang ada, sehingga mampu mewujudkan peningkatan mutu pembelajaran.

Strategi merupakan pola umum rentetan kegiatan yang harus dilakukan untuk mencapai tujuan tertentu. Kepala lembaga sebagai seorang pimpinan di suatu lembaga pendidikan perlu mempunyai strategi tertentu untuk mengembangkan motivasi pendidik dan

\footnotetext{
${ }^{4}$ Winardi, Dasar-Dasar Manajemen (Bandung: Mandar Maju, 2012), 9596.

${ }^{5}$ Saladin, Manajemen Strategi Dan Kebijakan Perusabaan (Bandung: Linda Karya, 2914), 1.
} 
tenaga kependidikan di lingkungan kerjanya. Kepala lembaga dilukiskan sebagai orang yang memiliki harapan tinggi bagi para staf dan para mahasiswa. Sebagai kepala lembaga di tuntut untuk mampu melakukan sebuah perubahan dan terobosan guna peningkatakan mutu dan kualitas lembaga. Dengan demikian, strategi merupakan pendekatan secara keseluruhan yang berkaitan dengan pelaksanaan gagasan, perencanaan, dan aktivitas dalam kurun waktu tertentu. Di dalam strategi yang baik terdapat koordinasi tim kerja, memiliki tema, mengidentifikasi faktor pendukung yang sesuai dengan prinsip-prinsip pelaksanaan gagasan secara rasional, efisien dalam pendanaan, dan memiliki taktik untuk mencapai tujuan secara efektif.

\section{Internalisasi Nilai-Nilai Religius}

Internalisasi menurut Kamus Ilmiah Populer adalah pendalaman, penghayatan terhadap suatu ajaran, doktrin atau nilai sehingga merupakan keyakinan atau kesadaran akan kebenaran doktrin atau nilai yang diwujudkan dalam sikap dan perilaku. ${ }^{6}$ Internalisasi pada hakikatnya adalah sebuah proses menanamkan suatu nilai pada seseorang yang akan membuat pola pikirnya dalam melihat realitas pengalaman. Internalisasi diartikan sebagai penghayatan, pendalaman, penguasaan secara mendalam. ${ }^{7}$ Jadi, $^{\circ}$ internalisasi adalah upaya yang dilakukan untuk memasukkan nilainilai ke dalam jiwa sehingga menjadi miliknya.

Muhaimin mengartikan bahwa nilai adalah suatu keyakinan dan kepercayaan yang menjadi dasar seseorang atau kelompok untuk memilih tindakan atau memilih suatu yang bermakna bagi kehidupannya. ${ }^{8}$ Rohmat Mulyana mengartikan nilai sebagai rujukan 2008), 75.

${ }^{6}$ Dahlan dkk., Kamus Ilmiah Populer (Yogyakarta: Arkola, n.d.), 267.

${ }^{7}$ Achmad Maulana, Kamus Ilmiah Populer Lengkeap (Yogyakarta: Absolut,

${ }^{8}$ Muhaimin, Nuansa Baru Pendidikan Islam (Jakarta: PT Raja Grafindo Persada, 2006), 148. 
dan keyakinan dalam menentukan pilihan. ${ }^{9}$ Senada dengan Sidi Gazalba sebagaimana yang dikutip Chabib Thoha mengartikan nilai adalah sesuatu yang bersifat abstrak, ideal, nilai bukan benda konkrit, bukan fakta, tidak hanya persoalan benar atau salah yang menuntut pembuktian empirik, melainkan penghayatan yang dikehendaki, disenangi, dan tidak disenangi. ${ }^{10}$

Nilai ialah prinsip atau hakikat yang menentukan harga atau nilai dan makna bagi sesuatu. Dalam kehidupan akhlak manusia yang menentukan nilai manusia, harga diri, dan amal serta sikapnya ialah prinsip-prinsip tertentu seperti kebenaran, kebaikan, kesetiaan, keadilan, persaudaraan, keprihatinan dan kerahiman. ${ }^{11}$ Nilai adalah suatu seperangkat keyakinan atau perasaan yang diyakini sebagai suatu identitas yang memberikan corak yang khusus kepada pola pemikiran, perasaan, keterikatan maupun perilaku. ${ }^{12}$ Dengan demikian nilai adalah bagian dari potensi manusiawi seseorang. Nilai adalah standar tingkah laku, keindahan, keadilan, dan efisiensi yang mengikat manusia dan sepatutnya dijalankan serta dipertahankan. Tentang beberapa uraian di atas dapat ditarik kesimpulan bahwa nilai merupakan sebuah konsep keyakinan terhadap suatu yang dipandang berharga olehnya dan mengarahkan tingkah laku seseorang dalam kehidupan sehari-hari sebagai makhluk hidup yang bermasyarakat.

Kata agama diucapkan oleh orang Barat dengan religios (bahasa latin), religion (bahasa Inggris, Perancis, dan Jerman) dan religie (bahasa Belanda). Dalam bahasa Arab kata dien berarti agama. 2004), 9 .

${ }^{9}$ Rohmat Mulyana, Mengartikulasi Pendidikan Nilai (Bandung: Alfabeta,

${ }^{10}$ Chabib Thaha, Kapita Selekta Pendidikan Islam (Yogyakarta: Pustaka Pelajar, 1996), 10.

${ }^{11}$ Abdul Aziz, Filsafat Pendidikan Islam: Sebuah Gagasan Membangun Pendidikan Islam (Surabaya: eLKAF, 2006), 102.

12 Abu dan Noor Salimi Ahmadi, Dasar-Dasar Pendidikan Agama Islam (Jakarta: Bumi Aksara, 2008), 202. 
Dien memiliki arti menguasai, menundukkan, patuh, hutang, balasan, dan kebiasaan. Pengertian ini juga sejalan dengan kandungan agama yang di dalamnya terdapat peraturan-peraturan yang merupakan hukum, yang harus dipatuhi penganut agama yang bersangkutan. Religius biasa diartikan dengan kata agama, agama menurut Frazer, sebagaimana dikutip Muhammad Faturrohman, adalah sistem kepercayaan yang senantiasa mengalami perubahan dan perkembangan sesuai dengan tingkat kognisi seseorang. Agama menurut Cliffort Greertz, sebagaimana dikutip Muhammad Faturrohman, agama bukan hanya masalah spirit, melainkan telah terjadi hubungan intens antara agama sebagai sumber nilai dan agama sebagai sumber kognitif. Agama dianggap sebagai hasil dari pengetahuan dan pengalaman manusia yang tidak jarang telah melembaga menjadi kekuatan mistis. ${ }^{13}$

Menurut Alim internalisasi nilai religius adalah suatu proses memasukkan nilai agar tertanam secara penuh di dalam hati, sehingga ruh dan jiwa bergerak berdasarkan ajaran Islam. Internalisasi ini dapat terjadi melalui pemahaman ajaran agama secara utuh dan diteruskan dengan kesadaran akan pentingnya ajaran agama serta ditemukannya posibilitas untuk merelisasikannya dalam kehidupan nyata. ${ }^{14}$

Internalisasi hakikatnya adalah sebuah proses menanamkan sesuatu. Sedangkan internalisasi nilai-nilai religius adalah sebuah proses menanamkan nilai-nilai religius. Internalisasi dapat diterapkan melalui pintu personal yakni melalui pintu perorangan khususnya para pendidik dan orang tua. Selanjutnya melalui pendekatan material, tidak hanya terbatas pada materi perkuliahan atau

13 Muhammad Faturrohman, Budaya Religius Dalam Peningkatan Mutu Pendidikan: Tinjauan Teoritik Dan Praktik Kontekstualisasi Pendidikan Agama Di Sekolah (Yogyakarta: Kalimedia, 2015), 48.

14 Muhammad Alim, Pendidikan Agama Islam: Upaya Pembentukan Pemikiran Dan Kepribadian Muslim (Bandung: P'T. Remaja Rosdakarya, 2006), 10. 
kurikulum tetapi juga bisa melalui kegiatan-kegiatan agama yang terdapat di kampus.

Internalisasi nilai-nilai religius adalah suatu proses yang mendalam dalam menghayati nilai-nilai agama Islam yang dipergunakan seseorang dalam menyelenggarakan tata cara hidup serta mengatur hubungan dengan Tuhan (habl min Allab), sesama manusia (babl min an-nas), dan alam sekitar. Semua nilai tersebut dipadukan dengan nilai-nilai pendidikan secara utuh, dan sasarannya menyatu dalam kepribadian seseorang, sehingga menjadi satu perilaku yang positif.

Stark dan Glock berpendapat yang dikutip oleh Ancok \& Suroso dalam buku yang berjudul Psikologi Islami, bahwa spiritualitas tidak lain adalah suatu komitmen religius, suatu tekad dan iktikad yang berkaitan dengan hidup keagamaan. Dalam uraiannya itu Stark dan Glock menyebutkan adanya 5 dimensi dari komitmen religius, yaitu:

1. Dimensi kepercayaan (belief), yaitu keyakinan akan kebenaran dari pokok-pokok ajaran imannya. Tak pelak lagi, ini merupakan unsur yang amat penting dalam kekristenan, bahkan juga di agama-agama lain. Tanpa keyakinan akan kebenaran dari pokokpokok ajaran iman, tentu seseorang tidak akan menjadi bagian dari komunitas orang beriman.

2. Dimensi praktis, terdiri dari dua aspek yaitu ritual dan devosional. Ritual diuraikan sebagai suatu ibadah yang formal. Secara asasi ritual adalah bentuk pengulangan sebuah pengalaman agama yang pernah terjadi pada masa awal pembentukan agama itu sendiri. Sedangkan yang dimaksudkan dengan devosional adalah ibadah yang dilakukan secara pribadi dan informal, seperti misalnya berdoa, berpuasa.

3. Dimensi pengalaman (experience), yaitu pengalaman berjumpa secara langsung dan subyektif dengan Tuhan. Atau dengan kata lain, mengalami kehadiran dan karya Tuhan dalam kehidupannya. Pengalaman keagamaan ini (religious experience) bisa menjadi awal 
dari keimanan seseorang, tetapi juga bisa terjadi setelah seseorang mengimani suatu agama tertentu. Entahkah pengalaman itu berada di awal ataupun di tengah-tengah, pengalaman ini berfungsi untuk semakin meneguhkan iman percaya seseorang.

4. Dimensi pengetahuan (knowledge), yaitu pengetahuan tentang elemen-elemen pokok dalam iman keyakinannya, atau yang sering kita kenal dengan dogma, doktrin atau ajaran gereja. Hal ini tentu saja sangat berkaitan dengan dimensi pertama (kepercayaan). Seseorang akan terbantu untuk menjadi semakin yakin dan percaya apabila ia mengetahui apa yang dipercayainya.

5. Dimensi etis, di mana umat mewujudkan tindakan imannya (act of faith) dalam kehidupan sehari-harinya. Dimensi etis ini mencakup perilaku, tutur kata, sikap dan orientasi hidupnya. Dan hal ini tentu saja dilandasi pada pengenalan atau pengetahuan tentang ajaran agamanya dan percaya bahwa apa yang diajarkan oleh agamanya adalah benar adanya. ${ }^{15}$

Ancok dan Suroso berpendapat bahwa konsep Glock \& Stark mempunyai kesesuaian dengan Islam. Walaupun tidak sepenuhnya sama, dimensi keyakinan dapat disejajarkan dengan akidah, dimensi praktik agama disejajarkan dengan syariah dan dimensi pengalaman disejajarkan dengan akhlak. Ketiga dimensi tersebut dijelaskan sebagai berikut: ${ }^{16}$

1. Akidah

Akidah secara etimologi yaitu kepercayaan. Sedangkan secara terminologi disamakan dengan keimanan, yang menunjukkan pada seberapa tingkat keyakinan seseorang terhadap kebenaran ajaran-ajaran agamanya yang bersifat fundamentalis dan dogmatis. Dalam Islam, isi dimensi keimanan menyangkut

${ }^{15}$ Djamaludin dan Fuat Nashori Suroso Ancok, Psikologi Islami: Solusi Islam Atas Problem-Problem Psikologi, cet. IV (Yogyakarta: Pustaka Pelajar, 2001), 77-78.

$$
16 \text { Ancok, } 79 .
$$


keyakinan tentang Allah, para Malaikat, para Nabi/Rasul, kitabkitab Allah, surga dan neraka serta qadha dan qadar.

2. Syariah

Syariah merupakan peraturan-peraturan yang mengatur hubungan langsung seorang muslim dengan Allah dan sesama manusia, yang menunjukkan seberapa patuh tingkat ketaatan seorang muslim dalam mengerjakan kegiatan-kegiatan ritual keagamaan yang dianjurkan dan diperintahkan oleh agamanya. Dalam Islam dimensi syariah meliputi pelaksanaan shalat, puasa, zakat, haji, membaca al-Qur'an, berdoa, berdzikir dan sebagainya.

3. Akhlak

Dimensi ini menunjukkan pada seberapa tingkatan muslim berperilaku dimotivasi oleh ajaran-ajaran agamanya, yaitu bagaimana individu berelasi dengan dunianya, terutama dengan sesama manusia. Dalam Islam dimensi ini meliputi perilaku suka menolong, kerjasama, menegakkan kebenaran, berlaku jujur, memaafkan, menjaga amanat dan menjaga lingkungannya.

Alasan digunakannya kelima dimensi tersebut karena cukup relevan dan mewakili keterlibatan keagamaan pada setiap orang dan bisa diterapkan dalam sistem agama Islam untuk diujicobakan dalam rangka menyoroti lebih jauh kondisi keagamaan mahasiswa muslim. Kelima dimensi ini merupakan satu kesatuan yang saling terkait satu sama lain dalam memahami religiusitas atau keagamaan dan mengandung unsur akidah (keyakinan), spiritual (praktek keagamaan), ihsan (pengalaman), ilmu (pengetahuan), dan amal (pengamalan).

Dimensi keyakinan (akidah) dalam Islam menunjukkan kepada tingkat keimanan seorang muslim terhadap kebenaran Islam, terutama mengenai pokok-pokok keimanan dalam Islam yang menyangkut keyakinan terhadap Allah SWT, para malaikat, kitabkitab, Nabi dan Rasul Allah, hari kiamat serta qadha dan 
qadar. ${ }^{17}$ Dalam Islam, dimensi praktek agama disebut dengan syari ${ }^{6}$ hb yang di dalamnya meliputi pengamalan ajaran agama dalam hubungannya dengan Allah secara langsung dan hubungan sesama manusia. Dimensi ini lebih dikenal dengan ibadah, sebagaimana yang disebut dalam kegiatan rukun Islam seperti shalat, zakat dan sebagainya serta ritual lainnya yang merupakan ibadah yang dilakukan setiap personal dan mengandung unsur transendental kepada Allah.

Dimensi pengamalan adalah ukuran sejauhmana perilaku seseorang dimotivasi oleh ajaran agamanya di dalam kehidupan. Misalnya menyedekahkan hartanya, membantu orang yang kesulitan, dan sebagainya. Setiap kegiatan ritual mempunyai konsekuensi logis berupa pahala dan dosa bagi yang melakukannya. Dalam kaitannya dengan hal ini, Islam mengenal konsep amr bi al-ma'ruf wa naby 'an almunkar. Amr bi al-ma'ruf diaplikasikan berbuat kebaikan pada sesama manusia, saling menghargai dan membantu sesama. Sedangkah naha 'an al-munkar diaplikasikan dengan menjauhi kemaksiatan, pergaulan bebas, tawuran, minum minuman keras, penggunaan obat terlarang, membantah orang tua dan seterusnya. Konsep ini mengajarkan keseimbangan antara unsur vertikal (habl min Allah) dan unsur horizontal (habl min an-nas) dalam diri setiap siswa.

Dimensi yang terakhir adalah pengetahuan keagamaan (religious knowledge) sebagai dimensi intelektual. Dimensi ini mengacu pada pengetahuan siswa atas dasar-dasar keyakinan, ritual-ritual, kitab suci dan tradisi-tradisi agama Islam. ${ }^{18}$

Muhaimin menjelaskan bahwa dalam proses internalisasi nilai melalui tiga tahapan, yaitu: ${ }^{19}$

1. Tahapan transformasi nilai

17 Ancok, 80.

18 Ancok, 81-82.

${ }^{19}$ Muhaimin, Paradigma Pendidikan Agama Islam: Upaya Untuk Mengefektifkan Pendidikan Agama Islam Di Sekolah (Bandung: PT. Remaja Rosdakarya, 2008), 301. 
Pada tahap ini dosen sekedar menginformasikan nilai-nilai yang baik dan nilai yang kurang baik kepada peserta didik, yang semata-mata merupakan komunikasi verbal, seperti berbohong merupakan perbuatan yang tidak baik.

2. Tahap transaksi nilai

Tahap ini merupakan tahap penanaman nilai dengan jalan melakukan komunikasi dua arah atau interaksi antar peserta didik dengan dosen bersifat interaksi timbal balik. Dalam tahap ini dosen tidak hanya menyajikan informasi tentang nilai yang baik dan yang buruk, tetapi juga terlibat untuk melaksanakan dan memberikan respon yang sama tentang nilai itu, yakni menerima dan mengamalkan nilai-nilai tersebut.

3. Tahap transisternalisasi

Pada tahap ini transinternalisasi nilai ini jauh lebih dalam dari pada sekedar transaksi. Dalam tahap ini penampilan pendidikan dihadapkan peserta didiknya bukan lagi pada sisi fisiknya, melainkan lebih kepada sikap mentalnya (kepribadiannya).

Menurut teori Peter L. Berger bahwa dialektika (interaksi sosio-kultural) fundamental terdiri dari tiga tahapan: ${ }^{20}$

1. Eksternalisasi adalah proses pencurahan diri manusia secara terus-menerus ke dalam dunia melalui aktivitas fisik dan mental atau usaha ekspresi manusia atas re-definisinya terhadap nilai yang selama ini diyakini sebagai kebenaran. Ekspresi ini diwujudkan kepada orang lain atau kelompok yang secara kuantitatif lebih besar dengan tujuan untuk mewarnai atau bahkan dalam kondisi ekstrim merubah nilai-nilai semula dengan nilai baru yang diyakini kebenarannya.

2. Objektivasi adalah tahap aktivitas manusia menghasilkan suatu realita objektif, yang berada di luar diri manusia atau sebagai upaya re-definisi nilai yang sudah ada pada kepercayaan dalam

${ }^{20}$ Peter L. Berger, Langit Suci: Agama Sebagai Realitas Sosial (Jakarta: LP3ES, 1991), 4.

Vol. 3, No. 1 (2018) 
kesadaran diri manusia. Dalam tahap ini, muncul pertanyaan kritis tentang fungsi, materi, dan beberapa hal lain terkait dengan nilai yang sudah dipahami tersebut. Hasil perenungan kembali yang terkadang dibumbuhi dengan tindakan kontemplatif ini, terkadang melahirkan proposisi nilai atau pemahaman baru yang secara subyektif dianggap lebih baik dari proposisi sebelumnya.

3. Internalisasi adalah tahap di mana realitas objektif hasil ciptaan manusia yang diserap oleh manusia kembali. Jadi, ada hubungan berkelanjutan antara realitas internal dengan realitas eksternal atau proses pemasukan nilai pada seseorang yang akan membentuk pola pikirnya dalam melihat makna realitas pengalaman. Nilai-nilai tersebut bisa jadi dari berbagai aspek baik agama, budaya, norma sosial dan yang lainnya. Pemaknaan atas nilai inilah yang mewarnai pemaknaan dan penyikapan manusia terhadap diri, lingkungan dan kenyataan di sekelilingnya.

Dalam sosiologi pengetahuan atau konstruksi sosial Berger, manusia dipandang sebagai pencipta kenyataan sosial yang obyektif melalui proses eksternalisasi, sebagaimana kenyataan obyektif mempengaruhi kembali manusia melalui proses internalisasi yang mencerminkan kenyataan subjektif. Konsep berpikir dialektis, Berger memandang masyarakat sebagai produk manusia dan manusia sebagai produk masyarakat.

\section{Strategi Kepala Lembaga Pengembangan Studi Islam (LPSI) dalam Menginternalisasikan Nilai-nilai Religius Mahasiswa}

Proses internalisasi nilai terjadi apabila individu menerima pengaruh tersebut dan bersedia bersikap dan mematuhi dan menjalankan pengaruh tersebut sesuai dengan apa yang ia yakini sesuai dengan sistem yang dianutnya. Jadi internalisasi nilai sangat penting dalam pendididikan agama Islam, terutama bagi lembagalembaga pendidikan yang notabane Islam. Karena pendidikan agama Islam merupakan pendidikan nilai sehingga nilai-nilai tersebut dapat tertanam pada diri mahasiswa, dengan pengembangan yang 
mengarah pada internalisasi nilai-nilai dasar Islam yang merupakan manifestasi manusia religius.

Proses internalisasi harus dilakukan secara continue yaitu penanaman nilai secara terus menerus dan berkesinambungan (continuing-learning) karena pada hakekatnya pendidikan agama Islam itu berlangsung sepanjang hayat. Penanaman nilai agama harus dilaksanakan secara berkesinambungan serta sejalan dengan fasefase perkembangan pada manusia. Proses internalisasi bisa dilakukan dalam pendidikan formal, dari mulai TK, SD, SMP, SMA/SMK, perguruan tinggi, bisa juga dilakukan oleh dosen agama ataupun dosen yang lain. ${ }^{21}$

Internalisasi nilai secara kontinyu akan memberikan pengalaman jiwa kepada mahasiswa sehingga terbentuk sebuah kebiasaan yang utuh, permanen, dan konsisten. Penanaman nilai yang dilakukan secara kontinyu dapat diterapkan dengan pembiasaan yang dilakukan secara berulang-ulang, sehingga menjadi kebiasaan atau cara-cara bertindak yang resistant, uniform, dan hampir tidak disadari oleh pelakunya (hampir otomatis).

Metode merupakan cara yang dalam fungsinya merupakan alat untuk mencapai tujuan kegiatan. Sebagai alat untuk mencapai tujuan tidak selamanya berfungsi secara memadai, oleh karena itu dalam memilih suatu metode yang akan dipergunakan dalam program kegiatan peserta didik, guru perlu mempunyai alasan yang kuat untuk faktor-faktor yang mendukung pemilihan metode tersebut. Metode merupakan bagian dari strategi kegiatan. Metode dipilih berdasarkan strategi kegiatan yang telah dipilih dan ditetapkan. Metode merupakan cara, yang dalam kerjanya merupakan alat untuk mencapai tujuan kegiatan. Namun suatu metode yang baik bagi objek tertentu belum tentu baik untuk objek

${ }^{21}$ Hary Noer Aly, Ilmu Pendidikan Islam (Jakarta: Logos, 1999), 184.

Vol. 3, No. 1 (2018) 
yang lainnya. ${ }^{22}$ Adapun metode dapat diartikan sebagai cara-cara atau langkah-langkah dalam menyampaikan sesuatu gagasan, pemikiran, atau wawasan yang disusun secara sistematik dan terencana berdasarkan teori, konsep, dan prinsip, suatu bidang disiplin ilmu. ${ }^{23}$

Para ahli pendidikan sepakat, bahwa salah satu tugas yang diemban oleh pendidikan adalah mewarisi nilai-nilai luhur budaya kepada peserta didik, termasuk nilai-nilai luhur agama sehingga dapat menjadi bagian dari kepribadiannya. Untuk menanamkan nilai-nilai luhur tersebut pada peserta didik bukan hal yang mudah. Usaha ini memerlukan kesabaran dan metode yang tepat. Fuaduddin TM menyebutkan bahwa untuk melakukan penanaman nilai pada mahasiswa diperlukan kiat khusus atau metode yang sesuai dengan karakter dan jiwa. Oleh karena itu, disarankan untuk menggunakan cara-cara yang akrab dan bisa dengan mudah diserap atau diterima oleh mahasiswa. Adapun cara-cara tersebut adalah memberi pembiasaan, keteladanan, nasehat, pengawasan, penghargaan dan hukuman terhadap mahasiswa. ${ }^{24}$

Metode dalam penanaman nilai-nilai keagamaan yang dapat digunakan sebagai panduan bagi pendidik:

1. Metode ceramah

Metode ceramah yaitu penerapan dan penuturan secara langsung oleh dosen dihadapan peserta didik. Metode ceramah ini sering kita jumpai pada proses-proses pembelajaran di sekolah mulai dari tingkat dasar sampai ke tingkat perguruan tinggi, sehingga metode seperti ini sudah dianggap sebagai metode yang terbaik bagi dosen untuk melakukan interaksi belajar mengajar.

${ }^{22}$ Ahmad Janan Asifudin, Mengungkit Pilar-Pilar Pendidikan Islam: Tinjauan Filosofis, cet. II (Yogyakarta: SUKA-Press UIN Sunan Kalijaga, 2010), 132.

23 Abuddin Nata, Perspektif Islam Tentang Strategi Pembelajaran (Jakarta: Kencana, 2011), 175-76.

${ }^{24}$ Fuaduddin TM, Pengasuhan Anak Dalam Keluarga Muslim (Jakarta: KAJ, 1996), 30. 
2. Metode Tanya Jawab

Metode tanya jawab adalah cara penyajian pelajaran dalam bentuk pertanyaan yang harus dijawab, terutama dari dosen kepada mahasiswa, tetapi dapat pula dari mahasiswa kepada dosen. Metode tanya jawab adalah yang tertua dan banyak digunakan dalam proses pendidikan, baik di lingkungan keluarga, masyarakat, maupun kampus.

3. Metode Demostrasi

Metode demonstrasi adalah metode mengajar dengan cara memperagakan barang, kejadian, aturan, dan urutan, melakukan suatu kegiatan, baik secara langsung maupun melalui penggunaan media pengajaran yang relevan dengan pokok bahasan atau materi yang sedang disajikan.

4. Metode Karyawisata

Metode karyawisata adalah cara penyajian pelajaran dengan membawa siswa ke luar untuk mempelajari berbagai sumber belajar yang terdapat di luar kelas. Kalaupun objeknya dibawa ke dalam kelas, keasliannya tidak dapat diamati lagi atau mengalami perubahan dan tidak akan memberikan gambaran pengetahuan dan pengertian yang sebenarnya mengenai objek yang akan diajarkan kepada mahasiswa.

5. Metode Penugasan

Metode penugasan adalah cara penyajian bahan pelajaran dimana dosen memberikan tugas tertentu agar peserta didik melakukan kegiatan belajar. Penugasan yang diberikan tersebut sebagai bentuk latihan agar suatu saat peserta didik dapat melaksanakan tugas yang sesungguhnya di masyarakat.

6. Metode Pemecahan Masalah

Metode pemecahan masalah adalah suatu metode mengajar dengan cara mahasiswa dihadapkan pada suatu masalah yang harus dipecahkannya berdasarkan data atau informasi yang akurat sehingga mendapatkan suatu kesimpulan. Sedangkan pemecahan masalah adalah suatu masalah dan memecahkannya berdasarkan 
data dan informasi yang akurat sehingga dapat diambil kesimpulan yang tepat dan cermat.

7. Metode Diskusi

Metode diskusi adalah metode mengajar yang sangat erat hubunganya dengan memecahkan masalah (problem solving). Metode ini lazim juga disebut sebagai diskusi kelompok (group discussion) dan resitasi bersama (socialized recitation).

8. Metode Simulasi

Metode simulasi adalah suatu metode pelatihan yang memperagakan sesuatu dalam bentuk tiruan yang mirip dengan keadaan yang sesungguhnya, simulasi sama dengan penggambaran suatu sistem atau proses dengan peragaan memakai model statistik atau pemeran.

9. Metode Eksperimen

Metode eksperimen adalah suatu cara mengajar, dimana mahasiswa melakukan suatu percobaan tentang sesuatu hal, mengamati prosesnya serta menuliskan hasil percobaanya, kemudian hasil pengamatan itu disampaikan ke kelas dan dievaluasi oleh dosen.

10. Metode Penemuan

Metode penemuan adalah cara penyajian pelajaran yang banyak melibatkan mahasiswa dalam proses-proses mental dalam rangka menemukan sesuatu yang diperlukan untuk pengembangan, penyempurnaan, dan perbaikan konsep. ${ }^{25}$

Seseorang akan bersedia mengamalkan ajaran agama atau memiliki kesadaran beragama jika dalam dirinya telah tertanam benih-benih keimanan. Pembiasaan dalam menjalankan praktikpraktik keagamaan di kampus maka sedikit demi sedikit akan menumbuhkan kesadaran dalam menjalankan syariat-syariat Islam pada peserta didik. Sehingga akan terbentuk generasi

${ }^{25}$ Nata, Perspektif Islam Tentang Strategi Pembelajaran, 181-95. 
bangsa yang berilmu pengetahuan dan bertakwa kepada Allah SWT.

Proses menumbuh kembangkan nilai-nilai religius pada mahasiswa dapat dilakukan sebagai berikut:

1. Pemberian Motivasi

Motivasi adalah "pendorongan", suatu usaha yang disadari untuk mempengaruhi tingkah laku seseorang agar ia bergerak hatinya untuk bertindak melakukan sesuatu sehingga mencapai hasil atau tujuan tertentu. ${ }^{26}$ Seorang dosen harus selalu memotivasi mahasiswa agar tumbuh pada diri mahasiswa dorongan untuk melakukan apa yang telah diajarkan. Dalam proses menumbuhkan nilai-nilai religius pada peserta didik, guru harus sering memberikan motivasi terutama pada saat proses pembelajaran berlangsung. Motivasi itu dapat berupa memberikan penjelasan tentang hikmah-hikmah jika kita melaksanakan apa yang diperintahkan Allah, seperti hikmah sholat dhuha, sholat berjamaah, mempererat tali silaturohmi, dan lain-lain sehingga mahasiswa akan termotivasi untuk mengamalkannya dalam kehidupan sehari-hari.

2. Pemberian Bimbingan/Arahan

Bimbingan lebih merupakan suatu proses pemberian bantuan yang terus menerus dan sistematis dari pembimbing kepada yang dibimbing agar tercapai kemandirian dalam pemahaman diri, pengarahan diri dan perwujudan diri dalam mencapai tingkat perkembangan yang optimal dan penyesuaian diri dengan lingkungannya. Bimbingan dapat berupa lisan, latihan, dan keterampilan.

3. Repetition (Pengulangan)

Pendidikan yang efektif dilakukan dengan berulangkali sehingga anak menjadi mengerti. Pelajaran atau nasihat apapun perlu dilakukan secara berulang, sehingga mudah dipahami anak.

${ }^{26}$ Akhyak, Profil Pendidik Sukses (Surabaya: eLKAF, 2005), 6.

Vol. 3, No. 1 (2018) 
Penguatan motivasi serta bimbingan pada beberapa peristiwa belajar mahasiswa, dapat meningkatkan kemampuan yang telah ada pada perillaku belajarnya. Hal tersebut mendorong kemudahan untuk melakukan pengulangan.

Berdasarkan teori Muhaimin, bahwa dalam proses internalisasi nilai melalui tiga tahapan, yaitu: tahapan tranformasi nilai, tahapan transaksi nilai, dan tahapan transisternalisasi. Tahapan internalisasi nilai Islam pada mahasiswa sudah masuk dalam tahap transaksi nilai dan tahap transisternalisasi nilai, sudah tidak lagi pada tahap transformasi nilai. Psikologis mahasiswa logikanya mengerti suatu hal yang baik dan yang buruk karena para mahasiswa sudah masuk dalam kategori balig (dewasa menurut Islam), yang seharusnya sudah mengerti mana yang salah dan mana yang benar, mana yang baik dan mana yang buruk. Untuk itu tahap yang perlu dikembangkan dalam hal penanaman nilai Islam untuk taraf mahasiswa adalah tahap transaksi nilai dan tahap transisternalisasi.

\section{Tahap Transaksi Nilai}

Tahap penanaman nilai dengan jalan melakukan komunikasi dua arah atau interaksi antar mahasiswa dengan dosen bersifat interaksi timbal balik. Dosen yang telah usai mengajar sebagian langsung menuju ke masjid dan sebagian yang lain menuju ke kantor dosen. Seluruh kantor-kantor bagian ditutup (terdapat tulisan "tutup" di depan pintu masuk). Dalam tahap ini dosen tidak hanya menyajikan informasi tentang nilai yang baik dan yang buruk, tetapi juga terlibat untuk melaksanakan dan memberikan respon yang sama tentang nilai itu, yakni menerima dan mengamalkan nilai-nilai tersebut.

Dalam hal berbusana di kampus, tidak hanya mahasiswa saja yang berbusana syar $i$ tetapi dosen juga perlu lebih sopan dan syar $i$ dari mahasiswa. Para dosen juga mengakhiri perkuliahan dengan segera apabila telah tiba waktu sholat. Hal ini menandakan bahwa mereka telah menanamkan dan mengamalkan nilai Islam kepada 
para mahasiswanya agar semua mahasiswa bisa ikut serta mengamalkannya pula. Dalam kegiatan kajian islami, terdapat juga para dosen yang ikut serta di dalamnya. Tidak hanya mahasiswa yang aktif, namun dosen juga ikut berperan aktif. Hal demikian menandakan adanya hubungan dua arah dalam proses internalisasi nilai Islam.

\section{Tahap Transisternalisasi}

Pada tahap ini, transisternalisasi nilai ini jauh lebih dalam dari pada sekedar transaksi. Dalam tahap ini penampilan pendidikan dihadapkan peserta didiknya bukan lagi pada sisi fisiknya, melainkan lebih kepada sikap mentalnya (kepribadiannya). Peneliti melihat para mahasiswa mempunyai kepribadian yang luhur, mereka mampu menerapkan nilai-nilai agama yang sudah mereka dapatkan selama ini. Mereka mengenakan busana muslim-muslimah yang syari dengan tanpa paksaan, karena mereka telah menyadari hukum dari pemakaian itu adalah wajib serta mempunyai gaya sosialisasi yang baik.

Sesuai dengan teori Hary Noer Aly bahwa proses Internalisasi harus dilakukan secara kontinyu yaitu penanaman nilai secara terus menerus dan berkesinambungan (continuing-learning) karena pada hakekatnya pendidikan agama Islam itu berlangsung sepanjang hayat. Untuk itu Kepala LPSI menetapkan mata kuliah yang harus diambil setiap semester oleh mahasiswa.

\section{Tabel 1: Daftar Mata Kuliah Studi Islam 2 SKS}

\begin{tabular}{ccc}
\hline Semester & Mata Kuliah & SKS \\
\hline 1 & Pengantar Ulumul Qur'an \& Hadis & 2 \\
\hline 3 & Akidah & 2 \\
\hline 5 & Fiqih & 2 \\
\hline 7 & Islam Interdisipliner & 2 \\
\hline
\end{tabular}




\section{Tabel 2: Daftar Mata Kuliah Studi Islam Nol SKS}

\begin{tabular}{ccc}
\hline Semester & Mata Kuliah & SKS \\
\hline 2 & Tahsinul Qur'an & 0 \\
\hline 4 & Kuliah Akhlak & 0 \\
\hline 6 & Kemuhammadiyahan & 0 \\
\hline 8 & Pengantar Ilmu Dakwah & 0 \\
\hline
\end{tabular}

Setiap semester ganjil seluruh mahasiswa wajib mengambil mata kuliah AIK dan wajib mengambil mata kuliah sertifkasi di setiap semester genapnya. Hal tersebut membuktikan bahwa penanaman nilai-nilai religius harus secara terus menerus atau kontinyu selama mahasiswa berada di kampus tersebut. Di luar dari hal akademik mahasiswa, bahwa penanaman nilai-nilai religius dapat pula berlangsung melalui kegiatan yang rutin diadakan di luar kelas, seperti kajian rutin untuk semua mahasiswa, dosen serta pegawai. Untuk melakukan penanaman nilai pada mahasiswa diperlukan kiat khusus atau metode yang sesuai dengan karakter dan jiwa mahasiswa.

\section{Kesimpulan}

Strategi Kepala LPSI dalam menginternalisasikan nilai-nilai religius mahasiswa merujuk kepada kesuaian aktifitas sosio-kultural mahasiswa. Dalam aktifitas sosio-kultural mahasiswa terdapat 3 tahapan yaitu, eksternalisasi nilai, objektivitas, dan internalisasi nilai. Pada tahapan eksternalisasi nilai, Kepala LPSI bekerjasama dengan panitia Program Pengenalan Kampus (PPK) dalam memberikan informasi penting terkait program islamisasi kampus. Pada tahap objektivitas, Kepala LPSI bekerjasama dengan seluruh dosen AIK dan sertifikasi, pembimbing kegiatan tahsinul-Qur'an dan organisasi 
mahasiswa dalam memberikan ilmu pengetahuan agama Islam. Pada tahapan internalisasi nilai, terdapat ranah akademik dan nonakademik, dalam ranah akademik para dosen menggunakan metode ceramah, tanya jawab, penugasan, pemecahan masalah, diskusi, demonstrasi, simulasi, dan persamaan referensi. Dalam ranah nonakademik, organisasi mahasiswa mengadakan kajian rutin, pelatihan dan lomba-lomba yang bertema Islami.

Upaya Kepala LPSI dalam penanaman nilai-nilai religius mahasiswa yaitu menetapkan beberapa kebijakan diantaranya: pertama, mewajibkan seluruh mahasiswa untuk menempuh mata kuliah AIK dan sertifikasi demi penanaman nilai-nilai Islam dalam diri mahasiswa. Kedua, kebijakan wajib mengikuti Tes Baca alQur'an (TBQ) serta bimbingan tahsinul Qur'an, untuk meningkatkan kemampuan mahasiswa dalam membaca dan memahami kitab suci agama Islam. Ketiga, kebijakan untuk berpakain/berbusana syar'i ketika berada dilingkungan kampus untuk menumbuhkan kesopanan dan kerapian mahasiswa.

\section{Daftar Pustaka}

Ahmadi, Abu dan Noor Salimi. Dasar-Dasar Pendidikan Agama Islam. Jakarta: Bumi Aksara, 2008.

Akhyak. Profil Pendidik Sukses. Surabaya: eLKAF, 2005.

Alim, Muhammad. Pendidikan Agama Islam: Upaya Pembentukan Pemikiran Dan Kepribadian Muslim. Bandung: PT. Remaja Rosdakarya, 2006.

Aly, Hary Noer. Ilmu Pendidikan Islam. Jakarta: Logos, 1999.

Ancok, Djamaludin dan Fuat Nashori Suroso. Psikologi Islami: Solusi Islam Atas Problem-Problem Psikologi. Cet. IV. Yogyakarta: Pustaka Pelajar, 2001.

Asifudin, Ahmad Janan. Mengungkit Pilar-Pilar Pendidikan Islam:

Tinjauan Filosofis. Cet. II. Yogyakarta: SUKA-Press UIN Sunan Kalijaga, 2010.

Aziz, Abdul. Filsafat Pendidikan Islam: Sebuah Gagasan Membangun Pendidikan Islam. Surabaya: eLKAF, 2006. 
Strategi Kepala Lembaga Pengembangan Studi Islam

Berger, Peter L. Langit Suci: Agama Sebagai Realitas Sosial. Jakarta: LP3ES, 1991.

Dahlan dkk. Kamus Ilmiah Populer. Yogyakarta: Arkola, n.d.

Faturrohman, Muhammad. Budaya Religius Dalam Peningkatan Mutu

Pendidikan: Tinjauan Teoritik Dan Praktik Kontekstualisasi

Pendidikan Agama Di Sekolah. Yogyakarta: Kalimedia, 2015.

Khotimah, Chusnul dan Muhammad Fathurrohman. Komplemen Manajemen Pendidikan Islam: Konsep Integratif Pelengkap Manajemen

Pendidikan Islam. Yogyakarta: Teras, 2014.

Maulana, Achmad. Kamus Ilmiah Populer Lengkap. Yogyakarta: Absolut, 2008.

Muhaimin. Nuansa Baru Pendidikan Islam. Jakarta: PT Raja Grafindo Persada, 2006.

- Paradigma Pendidikan Agama Islam: Upaya Untuk Mengefektifkan Pendidikan Agama Islam Di Sekolah. Bandung: PT. Remaja Rosdakarya, 2008.

Mulyana, Rohmat. Mengartikulasi Pendidikan Nilai. Bandung: Alfabeta, 2004.

Nata, Abuddin. Perspektif Islam Tentang Strategi Pembelajaran. Jakarta: Kencana, 2011.

Sahlan, Asmaun. Religiusitas Perguruan Tinggi: Potret Pengembangan Tradisi Keagamaan Di Perguruan Tinggi Islam. Malang: UIN-Maliki Press, 2011.

Saladin. Manajemen Strategi Dan Kebijakan Perusabaan. Bandung: Linda Karya, 2914.

Salusu, Salusu. Strategi Pengambilan Keputusan. Jakarta: Pressindo, 2014.

Thaha, Chabib. Kapita Selekta Pendidikan Islam. Yogyakarta: Pustaka Pelajar, 1996.

TM, Fuaduddin. Pengasuhan Anak Dalam Keluarga Muslim. Jakarta: KAJ, 1996.

Winardi. Dasar-Dasar Manajemen. Bandung: Mandar Maju, 2012. 